\title{
Economic Gain versus Ecological Damage from the Introduction of Non-native Freshwater Fish: Case Studies from Kenya
}

\author{
Phil Hickley ${ }^{1,2, *}$, Mucai Muchiri ${ }^{2}$, Robert Britton ${ }^{3}$ and Rosalind Boar ${ }^{4,2}$ \\ ${ }^{1}$ Environment Agency, United Kingdom; ${ }^{2}$ Moi University, Kenya; ${ }^{3}$ Bournemouth University, United Kingdom, \\ ${ }^{4}$ University of East Anglia, United Kingdom
}

\begin{abstract}
Non-native freshwater fish species that have been introduced to the inland waters of Kenya are listed and the consequences of stocking such fish are reviewed. Original species composition and lake ecosystem function can be detrimentally affected but, also, the introduction of non-native species can result in significant economic benefit. In the context of impact on recipient fish communities and the performance of exploited fisheries, the merits or otherwise of alien fish species introductions are discussed with the aid of two case histories; lungfish (Protopterus aethiopicus) in Lake Baringo and a number of species, particularly carp (Cyprinus carpio), in Lake Naivasha.
\end{abstract}

\section{INTRODUCTION}

Market-driven demands for non-native fish species are on the increase but so is the awareness of the associated potential problems. Notwithstanding this whole issue being highly controversial, the FAO database on introductions of aquatic species [1] indicates that, globally, introduced species contribute significantly to aquaculture $(39 \%)$, capture fisheries $(17 \%)$, ornamental trade (8\%) and bio-control $(6 \%)$.

Reasons for stocking fish are many and varied but generally fall within the four main categories of mitigation, restoration, enhancement, and the creation of new fisheries [2]. It is the creation of new fisheries that drives the introduction of non-native species. This is usually in an attempt to increase productivity by filling a perceived gap in the resident fish community or to change the principal target species to one that is more valuable in terms of food or local economy. There are, however, serious detrimental effects that can result from the stocking of non-native fish into new receiving waters:

- $\quad$ direct predation of resident species;

- competition with indigenous fish for food, cover or spawning sites;

- the introduction of new disease or parasites against which the resident populations have inadequate defences;

- $\quad$ hybridisation with resident fish causing reduced viability and fecundity of stocks;

- alteration or degradation of the required environment.

Although it is possible for species translocation to occur naturally, Bright [3] stated that the artificial movements of the present time differ fundamentally from natural range

\footnotetext{
* Address correspondence to this author at the Environment Agency, Hoo Farm Industrial Estate, Worcester Road, Kidderminster DY11 7RA, United Kingdom; Tel: +441562534161;

E-mail: phil.hickley@environment-agency.gov.uk
}

extension in the three respects of frequency, pervasiveness and impossible migration - Natural introductions are a rare event whereas it is claimed that the rate of artificial transfer of exotic species is a thousand times faster; the mixing of wholesale biota can rarely occur naturally and intense biotic mixing has moved from an occasional regional event to a chronic global phenomenon; previously impassable geographic barriers to migration are now easily crossed.

Whilst it is known that original species composition and lake ecosystem function can be detrimentally affected, it is also recognized that the introduction of non-native species can result in significant economic benefits. On many occasions these perceived economic benefits have provided powerful arguments for such stocking to be carried out, irrespective of the above risks. Introductions of fish species into areas outside their native range have a long history [4], with deliberate introductions for sport and food production intensifying from the early 1900s. Even with an awareness that the impacts of non-native fish stocking can be devastating, the temptation to seek recreational or economic reward remained.

Kenya is host to many instances of non-native fish introduction. Excluding the lacustrine Lake Victoria haplochromines, currently 206 species belonging to 38 families are known from Kenyan freshwaters [5]. Of these, at least 18 fish species were introduced, either deliberately or by accident such as escape from a fish farm. In addition, several Kenyan fish species have been translocated into waters where they did not occur naturally. These non-native fishes are listed in Appendix I with brief details on natural distribution, naturalized distribution, Kenyan history and impact. Typical examples of fish release and the reasons associated with it include:

\footnotetext{
- $\quad$ Rainbow trout, Oncorhynchus mykiss Walbaum - for sport fishing

- $\quad$ Largemouth bass, Micropterus salmoides La Cepède - for sport fishing
} 
- $\quad$ Nile perch, Lates niloticus (L.) - to produce edible protein

- $\quad$ Nile tilapia, Oreochromis niloticus (L.) - to augment declining stocks

- $\quad$ Redbelly tilapia, Tilapia zillii (Gervais) - to fill a vacant niche

- $\quad$ Guppy, Poecilia reticulata Peters - to control mosquito pupae

- $\quad$ Grass carp, Ctenopharyngodon idella Valenciennes - for weed control

- $\quad$ Common carp, Cyprinus carpio L. - for aquaculture

Six of the non-native fishes in Kenya are featured in the list of "100 of the World's Worst Invasive Alien Species" [6], a list designed to enhance awareness of the complexity and negative consequences of invasive alien species: $\mathrm{On}$ corhynchus mykiss, Salmo trutta L., Cyprinus carpio, Gambusia affinis Girard, Lates niloticus and Micropterus salmoides.

Perhaps the most studied and reported of any introduction of a non-native fish species is that of Nile perch, Lates niloticus, into Lake Victoria. Almost one hundred scientific papers and a vast amount of grey literature reports have been published. A good background to the subject comprises ten chapters in the book The Impact of Species Changes in African Lakes [7] and current issues and options for management of the Lake Victoria fisheries are discussed by Matsuishi et al. [8]. The argument in favour of releasing Nile perch was that the perch would prey upon the numerous haplochromine cichlids in the lake and thus convert a generally underutilized fish resource into a form of protein more readily available to local fishers and would provide a new sport fish for anglers [9]. Arguments against release were that a predatory fish cannot produce the same biomass as its prey species, that the native tilapia fishery would be affected and that the endemic species flocks would suffer irreparable damage $[10,11]$. Nile perch in Lake Victoria now sustains greatly increased fisheries [12], thus demonstrating economic and commercial success, with about 1.2 million people dependent directly or indirectly on the fishery for livelihoods. This has been at ecological cost, however, with extinction of haplochromines, loss of aquatic habitat and limnological degradation.

This paper considers the similar economic gain and ecological damage aspects of non-native fish introduction by reference to two further case histories: lungfish (Protopterus aethiopicus Heckel) in Lake Baringo and a number of species, particularly carp (Cyprinus carpio), in Lake Naivasha. The Rift Valley lakes of Kenya are of importance to national economy as natural assets, particularly in the context of tourism. In addition, those such as Lakes Baringo and Naivasha, which are fresh enough to support fish populations, provide support to the local economy by enabling a fishing industry.

\section{MATERIALS AND METHODS}

General review material and the information compiled in Appendix I was obtained from the literature; in particular $[4,5],[13,14]$. Commercial fish catch statistics for Lakes Baringo and Naivasha were obtained from the Fisheries Department of the Kenya Government. In Lake Naivasha, to monitor recruitment of carp, additional sampling of juvenile fish was carried out using mono-filament survey gill nets. Each survey net was $60 \mathrm{~m}$ long x $1.5 \mathrm{~m}$ deep with mesh size changes every $5 \mathrm{~m}$ (from 8.5-50 mm bar). Four nets were deployed for a sampling period of 12 days during July/August 2003 and October 2005. Nets were set daily at first light at locations covering the major habitat types (e.g. rocky shore, open water) and lifted after $5 \mathrm{~h}$ fishing. Fig. (1) shows the case study locations.

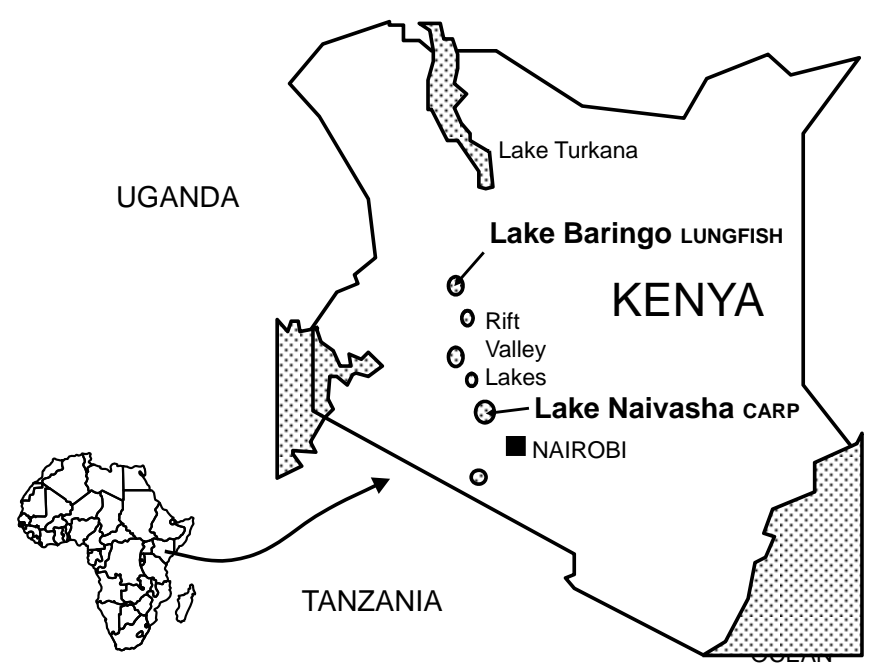

Fig. (1). Location of case study sites.

\section{CASE 1: BARINGO LUNGFISH}

\section{Description of Lake and Fishery}

Lake Baringo is approximately $140 \mathrm{~km}^{2}$, is $60 \mathrm{~km}$ north of the equator at an elevation of $900 \mathrm{~m}$ a.s.l., has a mean depth of $2.65 \mathrm{~m}$ and a maximum of $4.1 \mathrm{~m}$. Forty-six percent of the land in the district is too steep or too dry for agriculture and pastoralism is the main source of family income. Riparian use and ownership is variously private and communal. Lake Baringo became a Ramsar site in January 2002 [15] but the pressures on the lake's ecosystem and thus on the sustainability of its fishery is considerable [16]. The lake is subject to major fluctuations in water level and is extremely turbid, mainly due to soil erosion. This results from low vegetation cover, caused by deforestation and overgrazing, exacerbated by high intensity, sporadic rainfall on steep slopes. Lake Baringo has almost no submerged macrophytes at the present time, probably as a consequence of the poor light penetration.

The fish community of Lake Baringo comprises only a few species. The fishers use gill nets and long lines. Originally predominant was the endemic Oreochromis niloticus baringoensis (Trewavas) and this formed the basis of the commercial fishery. This was the only cichlid fish present in 1931 [17] and again in 1969 [18], with reports of other species being unsubstantiated. In 2002 it was reported [19] that $O$. $n$. baringoensis comprised $80 \%$ of the catch. Other species present in the fishery today are Protopterus aethiopicus, Clarias gariepinus (Burchell), Barbus intermedius australis (Banister) and Labeo cylindricus (Peters). L. cylindricus is classed as endangered [15] but probably is not [20]. In 1957, enough fish were being caught for a fish processing factory 


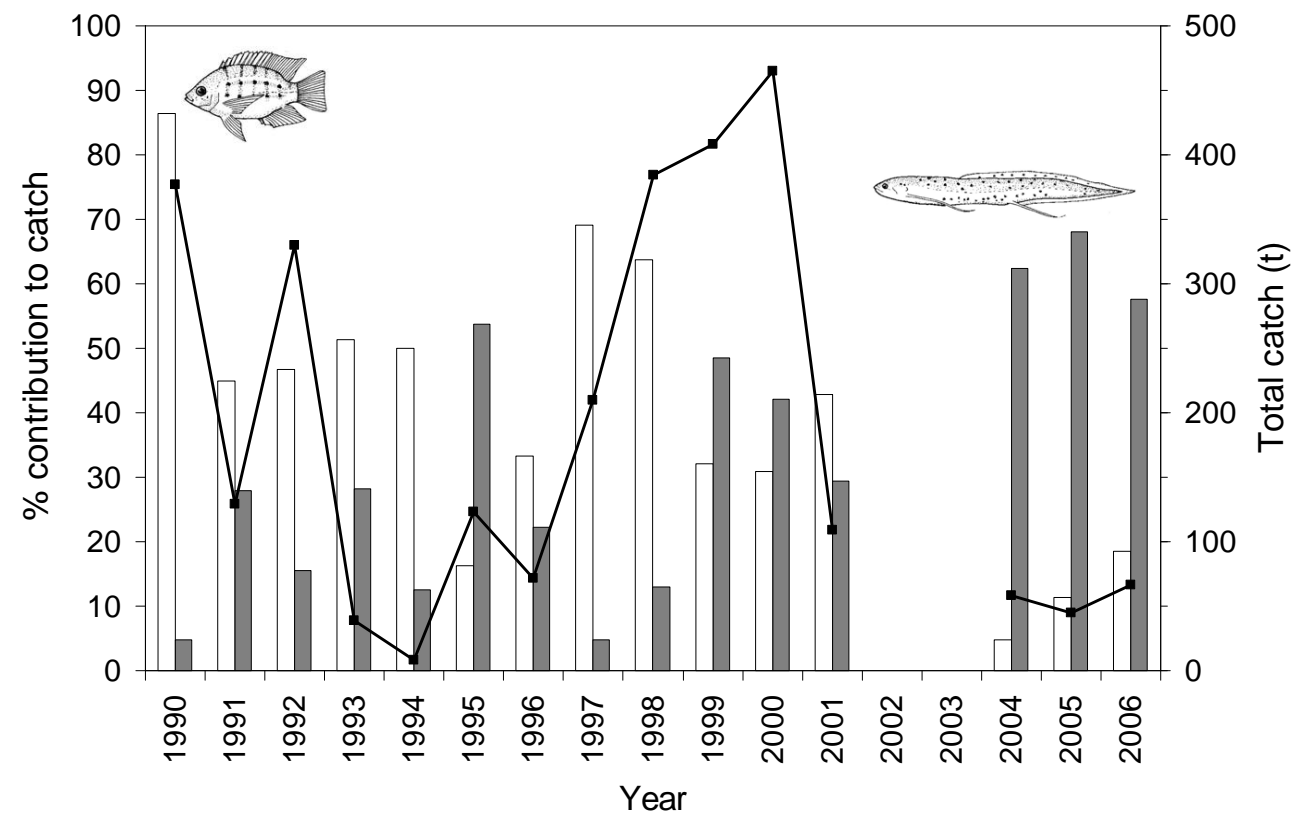

Fig. (2). Annual total fish catch (solid line) for the Lake Baringo fishery and the percentage contribution by weight to fish landings of $O$. $n$. baringoensis (white bars) and lungfish (grey bars).

to be opened; North-Lewis [21] states 1,500 good specimens a day. For the next twenty years or so fish remained plentiful at about $600-1000 \mathrm{t} \mathrm{yr}^{-1}$ but by 1989 catches had dropped to the point where the filleting plant was closed [22].

Fishing pressure has added to the environmental stresses on the fish populations and commercial catches have been affected detrimentally. The Lake Baringo fishery was closed from May 1993 to April 1994 and fishing was suspended again for an indefinite period from February 2002. Since reopening, catch returns have continued to be depressed, with a declared catch of only $58 \mathrm{t} \mathrm{y}^{-1}$ in 2004 compared with $465 \mathrm{t}$ $\mathrm{y}^{-1}$ in 2000. Prior to fishery closure, $O . n$. baringoensis was the dominant species in the commercial catches and comprised up to $86 \%$ of total catch (in 1990). However, in 2004, this endemic tilapia, taken by the commercial gill nets, contributed only $4 \%$ to total fish landings, compared with $62 \%$ for $P$. aethiopicus and $33 \%$ for C. gariepinus, both taken by long-line.

\section{Purpose and History of Introduction}

The marbled lungfish, Protopterus aethiopicus, was introduced to Lake Baringo in 1975. Seemingly, four juvenile lungfish, obtained from the Winam Gulf region of Lake Victoria, Kenya, were exhibited at the 1975 Agricultural Society of Kenya Show held in Nakuru, $13-14^{\text {th }}$ June 1975. One of these was then eaten and the other three released into to Lake Baringo [23]. The introduction was not planned and the incident largely forgotten until almost 10 years later when local fishers started noticing strange 'snake-like creatures' in their gill-net catches. Immigrant Luo fishers then introduced longline fishing, primarily targeting the lungfish. In 1998 De Vos et al. [24] commented that, whilst these first landings of $P$. aethiopicus were only just noticeable in 1984, landings of the lungfish can now exceed $50 \%$ of the total catch from the fishery (as per the 62\% in 2004 stated above).

\section{Impact}

It is unlikely that the introduction of $P$. aethiopicus has caused any significant and unsustainable effect on the resident species, either directly (e.g. predation) or indirectly (e.g. competition). Rather, the lungfish appears to be starting to fill the gap in fishers' catches left as O. n. baringoensis landings decline (Fig. 2).

\section{Economic Benefit}

Although recent attempts have been made to restore catches by regulating fishing effort, such as imposition of gill net mesh and fish size limits, the size classes and low commercial returns suggest that the $O . n$. baringoensis fishery might have collapsed. Therefore, at present, the only fish of significant commercial value, and thus providing income generation for the local fishers, is the introduced $P$. aethiopicus. Unfortunately, the local preference is for tilapia not lungfish as a food and, at US\$ $0.3 \mathrm{~kg}^{-1}$, lungfish is worth only a third that of $O$. $n$. baringoensis. The value could be increased, however, if efforts were to be made to increase the number of lungfish landed alive because, size for size, these are worth at least twice as much as dead lungfish; live lungfish being easily transported for resale in larger cities such as Nakuru, Nairobi and Eldoret [23].

\section{Conclusion}

$P$. aethiopicus is currently the dominant species in fish landings and, if this introduced species was absent, it is likely that the fishery would be no longer viable. Mlewa \& Green [23] consider the maintenance of a viable lungfish fishery in Lake Baringo to be of significance, to both the local community and the nation at large. In terms of why the lungfish can provide a fishery when the endemic tilapia cannot, it has wider environmental tolerances. As $P$. aethiopicus can survive swamp conditions and periods of low dissolved oxygen, and feeding relies on non-visual cues [25,26], Lake 


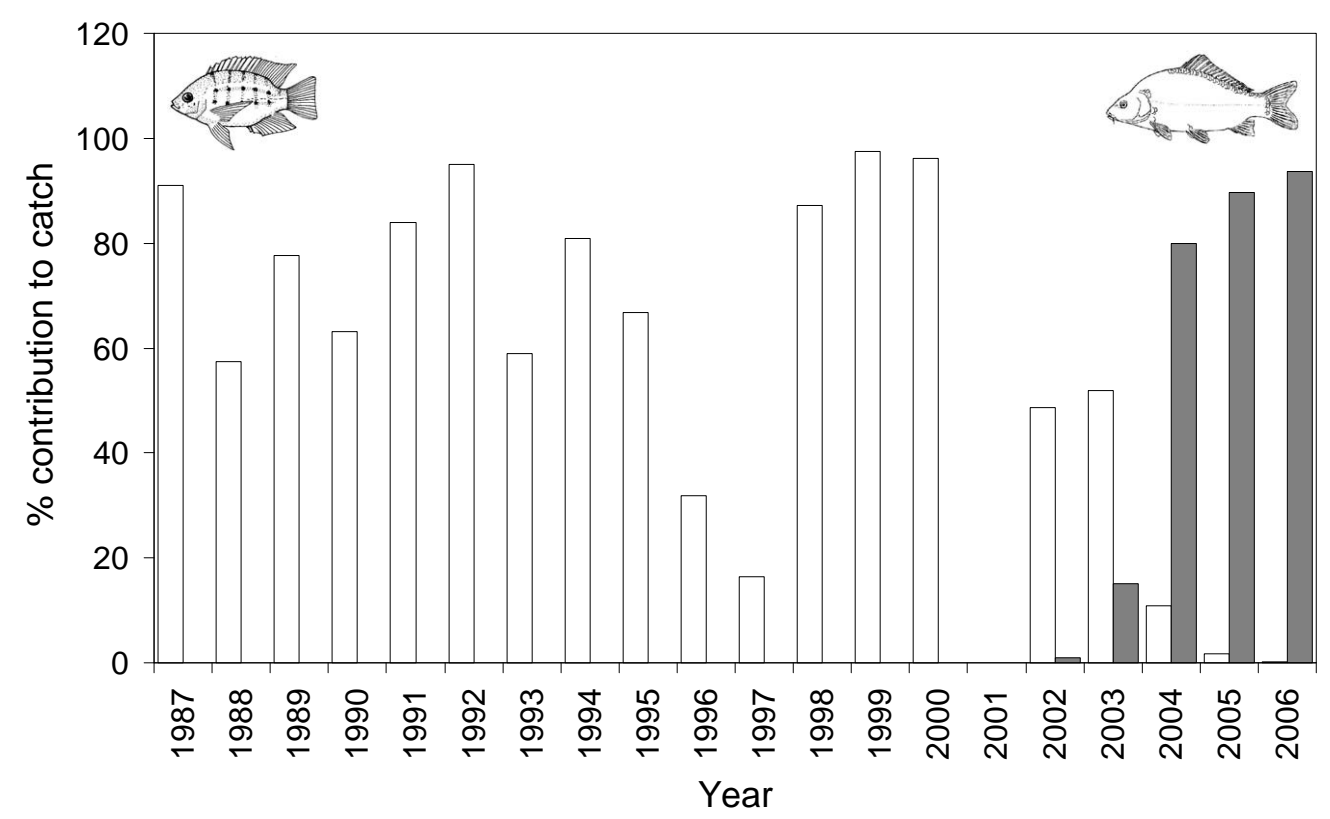

Fig. (3). Annual percentage contribution by weight of $O$. leucostictus (white bars) and carp (grey bars) to the commercial gill net catches of Lake Naivasha.

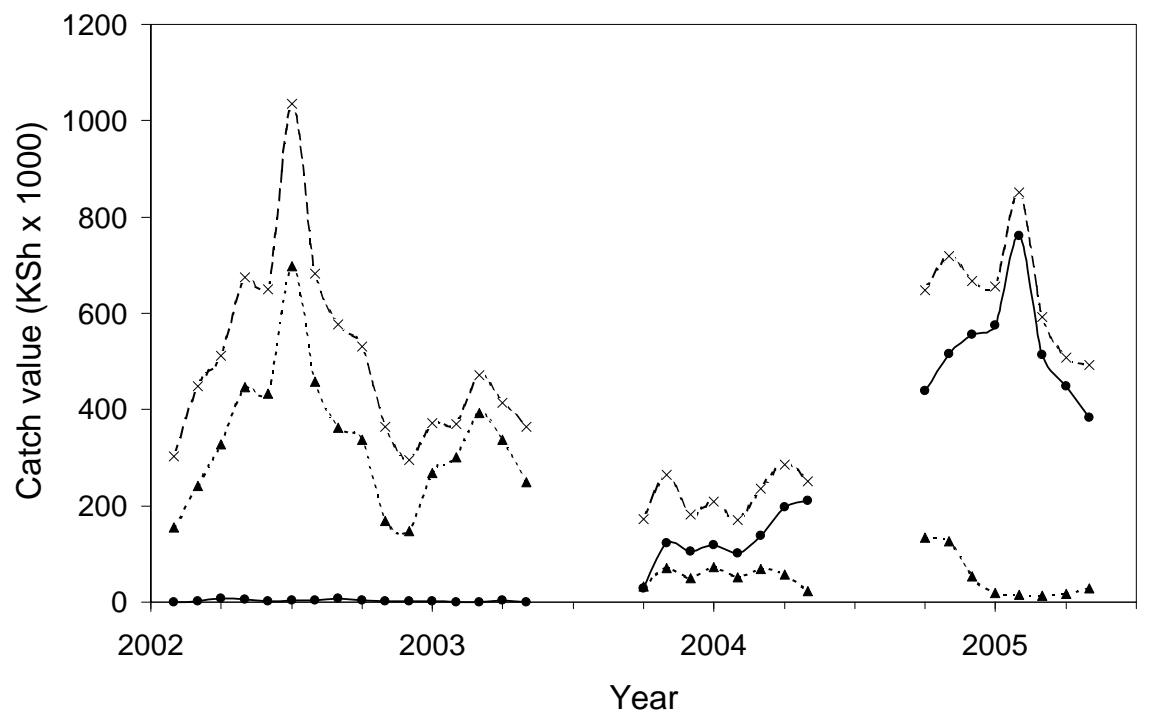

Fig. (4). Total annual market value of fish catches from Lake Naivasha (x, dashed line), with the market values of $O$. leucostictus ( $\boldsymbol{\Delta}$ dotted line) and carp (• solid line) shown separately.

Baringo's degraded habitat is unlikely to adversely impact on their population. Although limited remedial action is feasible within the catchment [16], the present conditions are likely to persist and so the presence of this tolerant species should continue to provide viable populations for exploitation. Continued exploitation will, however, require careful regulation because $P$. aethiopicus has poor resistance to overfishing [26], mostly due to low fecundity of females [27].

\section{CASE 2: NAIVASHA EXOTIC SPECIES}

\section{Description of Lake and Fishery}

Lake Naivasha is approximately $160 \mathrm{~km}^{2}$, is $190 \mathrm{~km}$ south of the equator at an elevation of $1890 \mathrm{~m}$ a.s.l., has a mean depth of $3.35 \mathrm{~m}$ and a maximum of $7 \mathrm{~m}$. It is bordered by Cyperus papyrus L. swamp which intercepts particles from eroded topsoil. Riparian ownership of Lake Naivasha is private. In a survey of local opinion on the importance of Lake Naivasha [16] the top three reasons for its value were fishing $20 \%$, drinking water $19 \%$ and irrigation $13 \%$. Lake Naivasha became a Ramsar site in April 1995 [28] but the pressures on the lake's ecosystem and fishery is considerable. The lake is subject to major fluctuations in water level and habitats are degraded as a consequence of riparian activity. There has been significant reduction in the total area of C. papyrus over the last 40 years as a consequence of both water level fluctuation and the reclamation of exposed stands to increased areas of cultivation [29]. In addition, Lake Naivasha has experienced an almost extirpation of its sub- 
Table 1. Summary of Changes to the Fish Community of Lake Naivasha

\begin{tabular}{|l|l|}
\hline \multicolumn{1}{|c|}{ Species } & \multicolumn{1}{c|}{ Date and Success of Fish Release } \\
\hline \hline Aplocheilichthys spec. "Naivasha" & Endemic. Probably extinct; last reported in 1962. Previously listed as A. antinorii (Vinciguerra) \\
\hline Oreochromis spirulus niger (Gunther) & Introduced in 1925. Disappeared by 1971. \\
\hline Micropterus salmoides (La Cepède) & Introduced in 1929, re-introduced in 1951. Present today. \\
\hline Tilapia zillii (Gervais) & Introduced in 1956. Present today. \\
\hline Oreochromis leucostictus (Trewevas) & Introduced unintentionally in 1956 with T. zillii. Present today. \\
\hline O. leucostictus x O.s. niger hybrid & Abundant in the early 1960s; due to back crossing with O. leucostictus disappeared by 1972. \\
\hline Oreochromis niloticus L. & Introduced in 1967. Disappeared by 1971. \\
\hline Gambusia sp. and Poecilia sp. & Introduced but dates unknown. Absent since 1977. \\
\hline Poecilia reticulata Peters & Introduced; date unknown. Recorded since 1982. Present today. \\
\hline Oncorhyncus mykiss (Walbaum) & Introduced into the River Malewa, dates unknown. Caught in the lake on rare occasions. \\
\hline Barbus paludinosus Peters & Invaded from inflowing rivers (introduced into rivers?). Recorded since 1982. Present today. \\
\hline Cyprinus carpio L. & Introduced by escape from a fish farm on the inflow river. First recorded in 2001. Present today. \\
\hline
\end{tabular}

merged macrophytes which, at best, are in a state of flux. A certain degree of eutrophication has been recorded [30] and is likely to have contributed to macrophyte disappearance. Also, submerged plants are decimated by crayfish when commercial trapping and predation are not sufficient to control their density [31].

The most significant riparian activity on Lake Naivasha is the large scale production of flowers for the European market and at least $50 \%$ of the perimeter of the lake is under irrigated agriculture of some description. As the labour-intensive flower industry developed, so did the need for housing, water and latrines [32]. The lake resources are also of critical importance to geothermal electricity generation, tourism, wildlife and conservation [33].

Resulting from a probable history of occasional drying out, Lake Naivasha when first studied (c.1900) had only one species of fish present. This was the endemic Aplocheilichthys species "Naivasha", previously referred to as $A$. antinorii (Vinc.) but it differs from this [5]. It was last recorded in 1962 [34]. Prior to the appearance of carp (Cyprinus carpio) in catches during 2002 [35], the only fish species in the lake were Oreochromis leucostictus (Trewavas), Tilapia zillii, Micropterus salmoides (largemouth bass), Barbus paludinosus Peters and Poecilia reticulata. Also present is the Louisiana red swamp crayfish, Procambarus clarkii (Girard). A commercial gill net fishery opened in 1959. The mean annual species composition of the fin-fish catch for the period 1987-2000 was O. leucostictus $71.7 \%$, T. zillii $8.8 \%$ and $M$. salmoides $19.5 \%$. There have been great fluctuations in the amount of fish landed and three phases of development have been identified: an initial "boom and bust", a period of stability and, most recently, a fishery performing poorly [36]. The maximum recorded total catch of $1150 \mathrm{t} \mathrm{yr}^{-1}$ was attained during 1970 in contrast with the lowest ever, 21

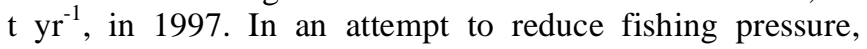
which has added to the environmental stresses on the fish populations, fishing in Lake Naivasha was banned throughout 2001. The fishery was re-opened with only 43 canoes, just over one third of the previous fleet, being allowed to fish. A closure was imposed from 1 June - 1 October 2003. This closed period is now an annual event and is combined with strict enforcement of gill net mesh sizes and fish size limits.

\section{Purpose and History of Introductions}

Since 1925 various fish introductions have been made, some successful and some not [37]. The tilapia, Oreochromis spirulus niger (Gunther), was introduced from the Athi River in 1925. The purpose of this release was to provide a forage fish ready for the American largemouth bass, Micropterus salmoides, destined to be introduced later at the suggestion of U.S. President T. Roosevelt who believed that sport fishing in East Africa needed improving [38]. A second cichlid, Tilapia zillii was released in 1956; this time the purpose being to establish a population for later commercial exploitation. The consignment of fish also contained some Oreochromis leucostictus and both species became well established. A summary of these and subsequent introductions to Lake Naivasha is given in Table $\mathbf{1}$.

Accepting that the fishery was underperforming, it had recently been proposed that yet more additional species should be introduced [36]. Based on prospective feeding guilds and the actual food web, Muchiri et al. [39] identified four areas in terms of food and space with respect to the potential for stocking additional species of fish. The most convincing case was that for a bottom feeder. Given that it was benthic oligochaetes and chironomid larvae which were under-utilized, one of the species of Mormyrus was proposed as likely to be a suitable candidate for introduction. It was considered essential that, if the concept of further introductions became acceptable, only African fish should be potential candidate species. It was, however, Cyprinus carpio that became the next species to be released.

In March 2001, whilst the fishery was closed, a fish eagle (Haliaeetus vocifer (Gaudin)) caught and landed a large carp approximately $680 \mathrm{~mm}$ in length (Higgins, personal communication). Subsequently, the presence of carp in the lake was confirmed. During the period $1^{\text {st }}-15^{\text {th }}$ March 2002, soon after 
the fishery was re-opened, 37 carp approximately $220 \mathrm{~mm}$ long and $0.4 \mathrm{~kg}$ in weight were taken by the gill net fishers. By the end of the year 1055 carp had been caught and their average weight had increased to $2.25 \mathrm{~kg}$ [35]. This introduction of carp was accidental with fish escaping from a fish farm adjacent to the River Malewa, Lake Naivasha's main inflow, and into which carp fingerlings had been stocked in 1997.

Sampling with survey gill nets in August 2003 produced eight juvenile carp of $85-140 \mathrm{~mm}$ fork length indicating that the species had bred and were thus in the process of becoming established. Analysis of carp length frequency from a combination of both survey and commercial gill nets in October 2005 showed the balanced structure of an established population, across a fork length range of 45-725 mm; 45-215 $\mathrm{mm}(n=76)$ caught in survey nets and $245-725 \mathrm{~mm}(n=$ 249) taken in the commercial fishery [40]. During 2004, there was a marked increase in the contribution of $C$. carpio to commercial catches and, by the end of 2006, the species comprised $93.7 \%$ of the total catch by weight (Fig. 3). Although the mean weight of landed carp was approximately $1.5 \mathrm{~kg}$, some individual fish exceeded $8 \mathrm{~kg}$.

\section{Impact}

The initial introductions of fish to Lake Naivasha (Table 1) destroyed the unique single species fish population. The endemic species of Aplocheilichthys was extirpated, presumably by the piscivorous bass, even before an accurate scientific description could be published [5].

The discovery of carp in Lake Naivasha raised considerable concern about the likelihood of the species dominating the lake through its potential for fast growth, early maturation and batch spawning, tolerance of poor water quality and destructive benthic foraging [41]. There are many global case studies of loss of macrophytes and increased turbidity following carp introduction. It is its feeding on bottom sediments, which uproots aquatic plants, suspends the sediment and increases water turbidity, that makes carp an unwanted species in some water bodies [42]. In the USA carp activity has controlled, uprooted or destroyed submerged vegetation and caused re-suspension of sediments $[43,44]$. Similarly, the presence of carp in some shallow lakes in the Netherlands has played a major role in increasing turbidity [45]. The Australian experience is that the carp has an extraordinary ability to cope with a broad variety of environmental extremes and that turbidity levels and carp densities are related $[46,47]$. In Lake Naivasha, however, the almost pristine habitat of clear water and abundant macrophytes has already gone due to the other environmental perturbations [32].

It was thought that any effects of carp on the submerged macrophytes of Lake Naivasha would be additive to the already detrimental impact of $P$. clarkii [31]. Although it was recognised that carp could be beneficial in consuming juvenile crayfish, it was also thought that for carp density to be sufficient for noticeable control might mean a carp population large enough to outweigh such benefit. In fact, evidence as to the nature of long-term impact is currently inconclusive. Adverse ecological impacts have not been readily apparent, with some macrophyte regeneration actually taking place, but this might change if the carp population continues to increase [40].

\section{Economic Benefit}

The initial suite of stocked species created a fishery that at one time sustained 104 fishing boats, albeit only 43 now. Fishing provides employment, and thus economic benefit, to fishers and their crew, families and associated traders. In 2004 \& 2005, mean prices of fish were: O. leucostictus, 85 KSh kg-1 (US\$ 1.10); C. carpio, $45 \mathrm{KSh} \mathrm{kg}^{-1}$ (US\$ 0.60). The price of tilapia is relatively high because it is more in demand than carp as a table fish. This is because it is a known species, suits traditional cooking methods and has a flavour that is preferred by local consumers.

The recent change in commercial catch composition means that $C$. carpio now dominates the market and the value of the O. leucostictus fishery is almost nil (Fig. 4). A typical fish landing from one canoe can be worth up to 8,000 KSh (US\$ 55). For a single day's work, even when shared amongst the crew, this is more income than from other manual employment in the District.

\section{Conclusion}

Without the release of alien species Lake Naivasha would not have had its viable bass and tilapia fishery from 1963 to 2003. Similarly, carp are currently providing an exploitable fish population. On balance, therefore, the introductions can be considered an economic and social success although, with hindsight, the selection of species type could have been better. Whether or not carp will prove to be detrimental to the ecology of Lake Naivasha is too early to judge. Its impact is difficult to separate from all other pressures on the lake and the population is still expanding.

Regarding the extinct lampeye, Aplocheilichthys spec. "Naivasha", it is impossible to know what its conservation value would have been had Lake Naivasha retained single fish species status. It is a matter for speculation as to whether the bass sport fishery, and the subsequent commercial tilapia fishery, would have been created if the present day approach to biodiversity had been extant in 1925 .

\section{DISCUSSION}

The performance of the commercial fisheries of Lakes Baringo and Naivasha remains poor, with continued depressed catches of the traditionally exploited species. Reliance upon recently introduced species with wide environmental tolerances now provides the only commercially viable option for the fisheries of both lakes. However, the ability of $P$. aethiopicus in Lake Baringo to withstand exploitation appears low and the presence of $C$. carpio in Lake Naivasha may be to the detriment of already degraded habitats. Therefore, whilst alien introductions might have provided these fisheries with a future, there is still a risk of unacceptable ecological cost. At present, however, far from being an exotic pest, the carp of Lake Naivasha actually provides a viable and profitable species for exploitation in a period when the catch returns of the other target species have declined markedly. Britton et al. [40], however, suggest that the positive status of carp is a condemnation of the extent of 
environmental and fishery decline that has occurred in Lake Naivasha since the 1970 s. They recommend that such alien introduction is not viewed as a panacea for other declining fisheries in degraded Kenyan lakes but, rather, it should act as a further warning of the threat posed by carp to fisheries currently based upon indigenous and naturalized species.

Thus, the case studies have supported the view that, in dealing with non-native introductions, very great care is needs to be exercised. It is important that best available information be used to identify, as far as is reasonably practicable, any risks of potential impact in an effort to evaluate correctly whether or not an introduction should proceed. Several international protocols exist to facilitate this and they should be rigorously applied [48-50]. If introductions are being considered, the critical questions to be answered are whether the action:

- $\quad$ could be an ecological disaster;

- will provide social and economic benefits;

- can be justified.

It must be recognized, and remembered, that the release of a non-native fish species into a new waterbody is effectively irreversible.

It is recommended that the following guiding principles, after Hickley \& Chare [51], should be established and adhered to by both stakeholders and fisheries managers:

- Demands for new sport fishing or commercial target species should be taken into account but new introductions should only be considered where there is a demonstrable social, economic, recreational or research benefit;

- Fish introductions should not in any circumstances be allowed to jeopardise the well being of naturally established ecosystems;

- There should be no detriment to the fisheries (stock, habitat, performance) of the recipient water, or to the viability of the fish involved in transfer and introduction.

Already, the need to control stocking with exotic fish has received international recognition. Resulting from a world conservation meeting held in Nairobi, Kenya, in 2002, the Nairobi Declaration [52] addressed "Conservation of aquatic biodiversity and use of alien species for aquaculture in Africa". Issues covered by recommendations within the declaration include: responsible introductions, conserving wild stocks, trans-boundary problems in fish transfer, strengthening access to information, controlling pathogen movement, raising awareness of risks of fish introduction and liability for adverse environmental impact.

Rose expressed the view that science has lost much credibility because of its head-in-the-sand approach, and modelling with hindsight has helped little to conserve fisheries [53]. Regarding the introduced fish species of Kenya, it is questionable as to what introductions would have taken place with the benefit of said hindsight. Given current knowledge of the scenario, what value would have been placed on the conservation of the Lake Victoria "Darwin's fish" haplochromines and would the Nile perch have been stocked? Whether a mass destruction of native species can ever be balanced by the benefits of the new fisheries is a complex question [54]. In the case of Lake Victoria, would it have been possible in reality to assess the relative merits of supporting the livelihood of 1.2 million people against conserving the evolutionarily significant species flock? Similarly, for the case examples presented here, how would any perceived need to conserve the endemic Baringo tilapia and the unique Naivasha lampeye have been balanced against demands to have fishery development? It is hoped that with modern day guidance on sustainable development and responsible fisheries management that any contemporary stocking regime would be less destructive.

\section{CONCLUSION}

The introduction of non-native fish into Kenyan waters has resulted in some ecological damage, some economic benefits, and significant fish stock management issues. From the evidence available from the case histories of Lakes Baringo and Naivasha, it could be concluded that such stocking is misguided in general and that the default position should be to leave non-native species where they belong; in their home waters.

\section{ACKNOWLEDGEMENTS}

The authors are grateful to the Fisheries Department of the Kenya Government for provision of catch statistics. Some of this paper draws on work carried out as part of the "Lakes of the Rift Valley" project sponsored by the Earthwatch Institute, Boston, U.S.A \& Oxford, England. The views expressed are those of the authors and not necessarily those of their parent organisations.

\section{APPENDIX I: SUMMARY INFORMATION FOR FISH SPECIES INTRODUCED OR TRANSLOCATED INTO KENYAN WATERS WHERE THEY WERE NOT PRESENT NATURALLY}

\section{Protopterus aethiopicus Heckel}

Natural distribution: Lakes Nabugabo, Albert, Edward, George and Tanganyika; upper White Nile; Lake Victoria drainage, Lake Kanyaboli and Lake Turkana.

Naturalized distribution: Lake Baringo. (Records from elsewhere in Kenya are based on misidentifications).

Kenyan history: Introduced to Lake Baringo in 1975.

Impact: Probably benign.

\section{Anguilla anguilla (L.)}

Natural distribution: Europe.

Naturalized distribution: Expected not to reproduce and thus not to survive in the wild in the future.

Kenyan history: Introduced into the Lake Victoria catchment via escape from fish farms in Uganda.

Impact: None known.

\section{Oncorhynchus mykiss Walbaum}

Natural distribution: Coastal drainage of North America, mainly west of the Continental divide. 
Naturalized distribution: Streams on Mount Kenya, in the Aberdare range, on the Mau Escarpment, in the Cherangani Hills and on Mount Elgon.

Kenyan history: In 1910, rainbow trout from South Africa were introduced to the Nairobi River on the northern slopes of Mount Kenya. By 1930, the species had been planted in most of the apparently suitable Kenyan waters and the first trout hatchery was opened in 1947.

Impact: Possible competition with native species.

\section{Salmo trutta $\mathbf{L}$.}

Natural distribution: Europe, Western Asia and parts of North Africa.

Naturalized distribution: Rivers and streams on Mount Kenya, in the Aberdare Mountains and in the Cherangani Hills.

Kenyan history: Original attempts to establish brown trout between 1906 and 1910 ended in failure but during 1920s populations became well established and self-sustaining in selected streams. Nonetheless the species was less adaptable than Oncorhynchus mykiss and now has a more limited distribution.

Impact: Possible competition with native species.

\section{Salvelinus fontinalis Mitchill}

Natural distribution: Northeastern North America.

Naturalized distribution: Unlikely that the species is now extant but were naturalized in some Aberdare streams.

Kenyan history: First introduced in 1949 in the hope that the species would breed in upland lakes with no inflowing stream.

Impact: Possible competition with native species.

\section{Barbus paludinosus Peters}

Natural distribution: In Kenya; Lake Victoria basin, Athi, Tana, Ewaso Nyiro and Pangani river systems, and Amboseli swamps.

Naturalized distribution: Additionally in Lake Naivasha and its inflow.

Kenyan history: Naturally distributed but not recorded for Lake Naivasha prior to 1982.

Impact: No noticeable impact in L. Naivasha; part of natural ecosystem elsewhere.

\section{Ctenopharyngodon idella Valenciennes}

Natural distribution: China and Eastern Siberia.

Naturalized distribution: Tana and Athi river systems but uncertain whether established.

Kenyan history: Introduced from Japan in 1969 for aquaculture and weed control.

Impact: Unknown.

\section{Carassius carassius (L.)}

Natural distribution: Europe and north-central Asia to northern China.

Naturalized distribution: Unknown if established.

Kenyan history: Introduced; details unknown.

Impact: Unknown.

\section{Cyprinus carpio $\mathbf{L}$.}

Natural distribution: Japan, China and central Asia.

Naturalized distribution: Masinga dam on Tana river and Lake Naivasha.

Kenyan history: Introduced from Uganda in 1969 for aquaculture.

Impact: Competion with indigenous tilapias and environmental damage.

\section{Gambusia affinis holbrooki Girard}

Natural distribution: North America in the Atlantic drainage and on Florida peninsula.

Naturalized distribution: Athi and Tana river systems, Lake Victoria drainage and formerly in Lake Naivasha.

Kenyan history: Introduced for mosquito control in the early 1960s.

Impact: Unknown.

\section{Poecilia latipinnia Lesueur}

Natural distribution: North ccarolina USA to Mexico.

Naturalized distribution: Lower reaches of Athi river system.

Kenyan history: Introduced for mosquito control.

Impact: Unknown.

\section{Poecilia reticulata Peters}

Natural distribution: Venezuela, Barbados, Trinidad, Northern Brazil and the Guyanas.

Naturalized distribution: Athi and Tana river systems, Lake Baringo, Upper Pangani drainage, Lake Naivasha, Northern Ewaso Nyiro and lake Victoria drainage.

Kenyan history: Introduced in from Uganda in 1956 for mosquito control.

Impact: Might be the cause of decline in native cyprinodonts in Tana system.

\section{Lates niloticus (L.)}

Natural distribution: The Congo, Volta, Nile and Niger river systems. Lakes Albert, Chad and Turkana.

Naturalized distribution: Lake Victoria.

Kenyan history: Introduced from Lake Albert in the mid 1950s and later introduced from Lake Turkana. First 
apppeared in catches in Kenyan waters of the Lake in 1966; thereafter, the expansion being explosive.

Impact: Contributed to the decline in native haplochromine fishes and deterioration in water quality.

\section{Lepomis cyanellus Rafinesque}

Natural distribution: East and Central North America.

Naturalized distribution: None.

Kenyan history: Unsuccessful introduction.

Impact: $\mathrm{n} / \mathrm{a}$.

\section{Lepomis macrochirus Rafinesque}

Natural distribution: Mississippi drainage USA.

Naturalized distribution: None.

Kenyan history: Introduced into some dams and reported from Tana River system afterwards. Introduction unsuccesful.

Impact: $\mathrm{n} / \mathrm{a}$

\section{Micropterus salmoides La Cepède}

Natural distribution: East and southern USA, North Mexico. Naturalized distribution: Lake Naivasha.

Kenyan history: Introduced into Lake Naivasha Introduced in 1929, several times during 1940s and in 1951. Escaped into Tana River from Sagana fish farm in 1961 but probably did not establish.

Impact: Extinction of endemic cyprinodont Aplocheilichthys spec. "Naivasha".

\section{Alcolapia grahami (Boulenger)}

Natural distribution: Lake Magadi.

Naturalized distribution: Lake Nakuru.

Kenyan history: Introduced to Lake Nakuru in 1953, 1959 and 1962. Possibly also introduced to Lake Elmentaita.

Impact: Disrupted natural Spirulina and flamingo balance by bringing fish and pelicans into the food web.

\section{Astatoreochromis alluaudi Pellegrin}

Natural distribution: Lake Victoria drainage and Lake Kanyaboli.

Naturalized distribution: Upper Athi system.

Kenyan history: Introduced into waters near Nairobi.

Impact: Unknown.

\section{Cichla ocellaris Bloch \& Schneider}

Natural distribution: Tropical South America.

Naturalized distribution: Unknown.

Kenyan history: Introduced to control stunted tilapia.

Impact: Unknown.

\section{Haplochromis spec. "Chala"}

Natural distribution: Tanzania

Naturalized distribution: Lake Chala.

Kenyan history: Introduced into Lake Chala crater lake in 1970s.

Impact: Unknown.

\section{Oreochromis andersonii (Castelnau)}

Natural distribution: Okavango drainage.

Naturalized distribution: Unknown if established in natural waters. Possibly in a dam at Nairobi.

Kenyan history: Introduced to Kenya in 1980 from Botswana for aquaculture purposes.

Impact: Unknown.

\section{Oreochromis leucostictus (Trewavas)}

Natural distribution: Endemic to lakes Edward, Albert and George.

Naturalized distribution: Lake Victoria basin, Lake Kanyaboli, Lake Naivasha and some dams in the country.

Kenyan history: Introduced 1953 onwards into the Kenyan waters of lake Victoria and in 1956 to Lake Naivasha.

Impact: In L. Victoria, competition with indigenous tilapias. In L. Naivasha, hybridised and out-competed another alien tilapia, Oreochromis spirulus niger (Gunther).

\section{Oreochromis macrochir (Boulenger)}

Natural distribution: Rivers of Zambezi basin including Lakes Mweru Bangweulu.

Naturalized distribution: Unknown if established in natural waters.

Kenyan history: Introduced to Kenya from Zambia in 1955 for aquaculture and started reproducing in ponds, although culture has been abandoned.

Impact: Risk of hybridization with more valuable species.

\section{Oreochromis niloticus (L.)}

Natural distribution: Basins of Rivers Niger, Chari, Benue, Volta, Gambia, Senegal and Chad in West Africa, through Congo basin and the Nile to the delta in Egypt. Sub-species $O$. $n$. baringoensis Trewavas endemic to Lake Baringo.

Naturalized distribution: Lake Victoria drainage and Lake Kanyaboli.

Kenyan history: Introduced to the Kenyan waters of Lake Victoria in 1957. Unsuccessful introduction to Lake Naivasha in 1967.

Impact: Hybridization, competition for food and possible transfer of parasites and disease.

\section{Oreochromis spirulus niger (Gunther)}

Natural distribution: Athi River and its tributaries, and upper tributaries of the Tana River. 
Naturalized distribution: Many dams.

Kenyan history: Introduced to many dams and river systems during 1920s. Introduced into Lake Naivasha in 1925, but disappeared through hybridization and competition with $O$. leucostictus. Also introduced to Lake Nakuru, which later dried up temporarily and caused the species to disappear.

Impact: Unknown.

\section{Pseudocrenilabrus multicolor victoriae Seegers}

Natural distribution: Lake Victoria basin, Lake Kanyaboli. Naturalized distribution: Possibly where introduced (below). Kenyan history: Introduced to Upper Athi and upper Tana systems.

Impact: Unknown.

\section{Tilapia rendalli (Boulenger)}

\section{Natural distribution: West and Central Africa.}

Naturalized distribution: Lake Victoria and many systems and dams including Pangani, Athi and Tana.

Kenyan history: Introduced in 1955 to Lake Victoria for aquaculture and fishing, and to the Tana River.

Impact: Possible hybridization.

\section{Tilapia zillii (Gervais)}

Natural distribution: From West Africa eastward through Chad and Nile basins, Lakes Albert and George, and northward into Israel and the Jordon valley, including Lake Turkana.

Naturalized distribution: Lake Victoria system, Lake Naivasha and Tana River.

Kenyan history: Introduced from Lake Albert to lake Victoria in 1953-1955. Tranlocated to Lake Naivasha in 1956 to supplement diet of introduced Micropterus salmoides.

Impact: In Lake Victoria, competition for spawning grounds with endemic Oreochromis variabilis (Boulenger).

\section{REFERENCES}

[1] Garibaldi L, Bartley D. The database on introductions of aquatic species (DIAS): the web site. FAO Aquac Newsl 1999; 21: 20-24.

[2] Hickley P. Stocking and introduction of fish - a synthesis. In: Cowx IG, Ed. Rehabilitation of Freshwater Fisheries. Fishing News Books, Blackwell Scientific Publications: Oxford 1994; 247-54.

[3] Bright C. Life Out of Bounds. Bio-Invasions in a Borderless World. W. W. Norton \& Company: London \& New York 1998.

[4] Lever C. Naturalized fishes of the World. Academic Press 1996.

[5] Seegers, L, De Vos L, Okeyo DO. Annotated checklist of the freshwater fishes of Kenya (excluding the lacustrine haplochromines from Lake Victoria). J East Afr Nat Hist 2003; 92: 11-47.

[6] Lowe S, Browne M, Boudjelas S, De Poorter M. 100 of the World's Worst Invasive Alien Species A selection from the Global Invasive Species Database. Invasive Species Specialist Group (ISSG) 2000.

[7] Pitcher TJ, Hart PJB, Eds. The impact of species changes in african lakes. Chapman and Hall: London 1995.

[8] Matsuishi T, Muhoozi L, Mkumbo O, et al. Are the exploitation pressures on the Nile perch fisheries resources of Lake Victoria a cause for concern? Fish Manag Ecol 2006; 13: 53-71.
Harrison K, Crimmen O, Travers R, Maikweki J, Mutoro D. Balancing the scales in Lake Victoria. Biologist 1989; 36: 189-91.

[10] Graham M. The Victoria Nyanza and its fisheries: a report on the fish survey of Lake Victoria 1927-1928 and appendices. Crown Agents for the Colonies: London 1929.

[11] Fryer G. Concerning the proposed introduction of Nile perch into Lake Victoria. East Afr Agric J 1960; 25: 267-70.

[12] Cowx IG, Van der Knaap M, Muhoozi LI, Othina A. Improving fishery catch statistics for Lake Victoria. Aquat Ecosyst Health Manage 2003; 6: 299-310.

[13] Welcomme RL. International introductions of inland aquatic species. FAO Fisheries Technical Paper 294. FAO: Rome 1988.

[14] Fishbase [homepage on the internet]. Available from: http://www.fishbase.org

[15] Ramsar. Information Sheet on Ramsar Wetlands (RIS) - Kenya, Lake Baringo 2002. Available from: http://www.ramsar.org/ ris_kenya_baringo1.htm

[16] Hickley P, Muchiri SM, Boar RR, et al. Habitat degradation and subsequent fishery collapse in Lakes Naivasha and Baringo, Kenya. Ecohydrol Hydrobiol 2004; 4: 503-17.

[17] Worthington EB, Ricardo CK. Scientific results of the Cambridge Expedition to the East African lakes, 1930-1. No.15. The fish of Lake Rudolf and Lake Baringo. J Linn Soc Lond 1936; 39: 353-89.

[18] Ssentongo GW, Mann MJ. On the fish species of Lake Baringo. Report of the East Africa Freshwater Fish Research Organisation for 1970 (issued 1971); 20-27.

[19] Aloo PA. Effects of climate and human activities on the ecosystem of Lake Baringo. In: Odada EO, Olago DO, Eds. The East African Great Lakes: Limnology, Paleolimnology and Biodiversity. Advances in Global Research 12. Kluwer Academic Publishers 2002; 335-48.

[20] Britton JR, Harper DM. Assessing the true status of the fish species Labeo cylindricus (Peters 1868) (Teleostei: Cyprinidae) in Lake Baringo, Kenya. Afr J Aquat Sci 2005; 30 (2): 203-5.

[21] North-Lewis M. A guide to Lake Baringo and Lake Bogoria. Horizon Books 1998.

[22] TVE. 2003 Earth Report: Healing the Rift. Available from: http://www.tve.org/earthreport/archive/doc.cfm?aid=826.

[23] Mlewa CM, Green JM. Translocation of marbled African lungfish, Protopterus aethiopicus (Telostei: Protopteridae), and its fishery in Lake Baringo, Kenya. Afr J Aquat Sci 2006; 31: 131-6.

[24] De Vos L, Pertet F, Vanlerberghe K, Nuguti S, Ntiba MJ. Present status of the fish fauna and fisheries of Lake Baringo, Kenya. In: Proceedings of International Conference for the Paradi Association and the Fisheries Society of Africa, Grahamstown (South Africa). FISA/PARADI: Grahamstown 1998; 13-18.

[25] Greenwood PH. The natural history of African lungfish. J Morphol 1986; (Supplement 1): 163-179.

[26] Goudswaard PC, Witte F, Chapman CJ. Decline in the African lungfish (Protopterus aethiopicus) in Lake Victoria (East Africa). East Afr Wildlife Soc 2002; 40: 42-52.

[27] Mlewa CM, Green JM. Biology of the Marbled lungfish Protopterus aethiopicus Heckel in Lake Baringo, Kenya. Afr J Ecol 2004; 42: 338-45.

[28] Wetlands International. 2003 Ramsar Sites Database, Lake Naivasha 1KE002. Available from: http:/www.wetlands.org/ repo rts/ris/1KE002en.pdf

[29] Boar RR. Responses of a fringing Cyperus papyrus L. Swamp to changes in water level. Aquat Bot 2006; 84: 85-92.

[30] Kitaka N, Harper DM, Mavuti KM. Phosphorus inputs to Lake Naivasha, Kenya, from its catchment and the trophic state of the lake. Hydrobiologia 2002; 488: 73-80.

[31] Hickley P, Harper DM. Fish community and habitat changes in the artificially stocked fishery of Lake Naivasha, Kenya. In: Cowx IG, Ed. Management and ecology of lake and reservoir fisheries. Fishing News Books, Blackwell Scientific Publications: Oxford 2002; 242-54.

[32] Enniskillen. The Lake Naivasha Management Plan - consensusbuilding to conserve an international gem. Hydrobiologia 2002; 488: ix-xii.

[33] Harper DM, Mavuti KM, Muchiri SM. Ecology and management of Lake Naivasha, Kenya, in relation to climatic change, alien species introductions and agricultural development. Environ Conserv 1990; 17: 328-36.

[34] Elder HY, Garrod DT, Whitehead PJP. Natural hybrids of the African cichlid fishes Tilapia spirulus nigra and T. leucosticta, a case of hybrid introgression. Biol J Linnean Soc 1971; 3: 103-46. 
[35] Hickley P, Muchiri SM, Britton JR, Boar RR. Discovery of carp (Cyprinus carpio) in the already stressed fishery of Lake Naivasha, Kenya. Fish Manag Ecol 2004; 11: 139-42.

[36] Hickley P, Bailey RG, Harper DM, et al. The status and future of the Lake Naivasha fishery, Kenya. Hydrobiologia 2002; 488: 18190.

[37] Muchiri SM, Hickley P. The fishery of Lake Naivasha, Kenya. In: Cowx IG, Ed. Catch Effort Sampling Strategies: Their application in freshwater fisheries management. Fishing News Books, Blackwell Scientific Publications: Oxford 1991; 382-92.

[38] Robbins WH, MacCrimmon HR. The black-bass in America and overseas. Biomanagement Research Enterprises: Sault Ste. Marie, Ontario 1974.

[39] Muchiri SM, Hickley P, Harper DM, North E. The potential for enhancing the fishery of Lake Naivasha, Kenya. In: Cowx IG, Ed. Rehabilitation of Freshwater Fisheries. Fishing News Books, Blackwell Scientific Publications: Oxford 1994; 348-57.

[40] Britton JR, Boar RR, Grey J, Foster J, Lugonzo J, Harper DM. From introduction to fishery dominance: the initial impacts of the invasive carp Cyprinus carpio in Lake Naivasha, Kenya, 1999 to 2006. J Fish Biol 2007; 71 (Supplement D): 239-57.

[41] Koehn JD. Carp (Cyprinus carpio) as a powerful invader of Australian waterways. Freshwater Biol 2004; 49: 882-94.

[42] Petr T. Interactions between fish and aquatic macrophytes in inland waters. A review. FAO Fisheries Technical Paper No. 396. FAO: Rome 2000.

[43] Crivelli AJ. The destruction of aquatic vegetation by carp. Hydrobiologia 1983; 106: 37-41.

[44] Crowder LB, Painter DS. Submerged macrophytes in Lake Ontario: current knowledge, importance, threats to stability, and needed studies. Can J Fish Aquat Sci 1991; 48: 1539-45.

[45] Meijer ML, De Haan MW, Breukelaar AW, Buiteveld H. Is reduction of the benthivorous fish an important cause of high transpar- ency following biomanipulation in shallow lakes? Hydrobiologia 1990; 200-201: 303-15.

[46] King AJ, Robertson AI, Healey MR. Experimental manipulations of the biomass of introduced carp (Cyprinus carpio) in billabongs. I. Impacts on water-column properties. Mar Freshwater Res 1997; 48: 435-43.

[47] Robertson AI, Healey MR, King AJ. Experimental manipulations of the biomass of introduced carp (Cyprinus carpio) in billabongs. II. Impacts on benthic properties and processes. Mar Freshwater Res 1997; 48: 445-54.

[48] Turner GE. Code of practice and manual of procedures for consideration of introductions and transfers of marine and freshwater organisms. FAO European Inland Fisheries Advisory Commission (EIFAC) Occasional Paper 23. FAO: Rome 1988

[49] FAO. Code of Conduct for Responsible Fisheries. FAO: Rome 1995.

[50] FAO. Precautionary Approach to Capture Fisheries and Species Introductions. FAO Technical Guidelines for Responsible Fisheries 2. FAO: Rome 1996.

[51] Hickley P, Chare S. Fisheries for non-native species in England and Wales: angling or the environment? Fish Manag Ecol 2004; 11: 203-12.

[52] ICLARM. The Nairobi Declaration: Conservation of aquatic biodiversity and use of genetically improved and alien species for aquaculture in Africa. Expert consultation held in Nairobi, Kenya, 20-23 February 2002; ICLARM 2002.

[53] Rose GA. The trouble with fisheries science! Rev Fish Biol Fish 1997; $7: 365-70$

[54] Goldschmidt T, Witte F. Explosive speciation and adaptive radiation of haplochromine cichlids from lake Victoria. An illustration of the scientific value of a lost species flock. Mitt Internat Verein Limnol 1992; IVTMAS 23: 101-107.

(C) Hickley et al.; Licensee Bentham Open.

This is an open access article licensed under the terms of the Creative Commons Attribution Non-Commercial License (http://creativecommons.org/licenses/by-nc/3.0/) which permits unrestricted, non-commercial use, distribution and reproduction in any medium, provided the work is properly cited. 